\title{
E-GOVERNMENT IN LIBYA
}

\author{
Aref Busoud, \\ Dejan Živković
}

Singidunum University, 32 Danijelova Street, Belgrade, Serbia
Correspondence:

Aref Busoud

e-mail:

arefabosaoud@yahoo.com

\begin{abstract}
:
E-government represents a coeval model of communication, which is a solution for complicated processes within government, business and individuals. The main goals of E-government are: reducing of government spending and direct cost of services, better coordination and communication between government institutions, private sector and citizens. E-government consists of three types of E-services: government to citizen (G2C), government to business (G2B), and government to government $(\mathrm{G} 2 \mathrm{G})$. Libya is a developing country that attempts to establish e-government services to improve government functions, productivity and efficiency of government agencies as well simplifying complicated procedures for their citizens. In this paper, we will present benefits that Libya will gain from this project and describe e-government initiatives and most significant advantages and disadvantages of this kind of project.
\end{abstract}

Key words:

e-government, Libya, electronic services, G2C, G2B, G2C.

\section{INTRODUCTION}

National and local governments from every region of the world, are attempting to put in information on the World Wide Web (W.W.W.), and to use this mechanism for simplifying the operations that were complicated and to interact with citizens and private sector electronically. The main goals of E-government are to reduce government spending and direct cost of transactions. As a results, it reduced costs of services, improved coordination between government agencies and simplified administration. Furthermore, it has led to openness to other countries, identification of new technologies, improvement of services through electronic reports, and achievement of trust and stability among citizens, and making of easiest way to access electronic services through the portals. The main purpose is to keep transparency and accurate information for society and to promote democracy.

Standard types of services include, issuing identity cards, passports, birth and marriage certificates, judicial decisions, request a building permit, paying taxes, duties and new or used automobile registration, public libraries (availability of indexes, and research tools), enrollment in higher education, address change, and health-related services (providing interactive medical advice, taking appointments), voter registration and pay any required fees using credit cards. 


\section{DEFINITION OF E-GOVERNMENT}

E-government (electronic government) represents a set of services, which are provided through electronic communication to public and private sector.

Services that E-Government is provides include:

1. Government to Citizen (G2C), are services for its citizens.

2. Government-to-Business (G2B), are services for private sector, which are simplified and brought up less cost of transactions.

3. Government-to-Government (G2G) is a set of services, which are representing communication between different facilities of the local government, and international cooperation between high governments of other countries around the world [7].

For efficient use of these services it is necessary that there is coordination of activities and good cooperation between the public and private sector, as well as citizens and government.

Electronic government refers to implementation of information technologies and systems, communication technologies and other web-based telecommunication technologies to improve the efficiency of service delivery to the public sector and government agencies [13].

Advantages over the system based on extensive paperwork and numerous administration staff is: less cost of services and reduce of spent time during their realization. The advantage is offering good efficiency, easier accessibility and lower costs of services.

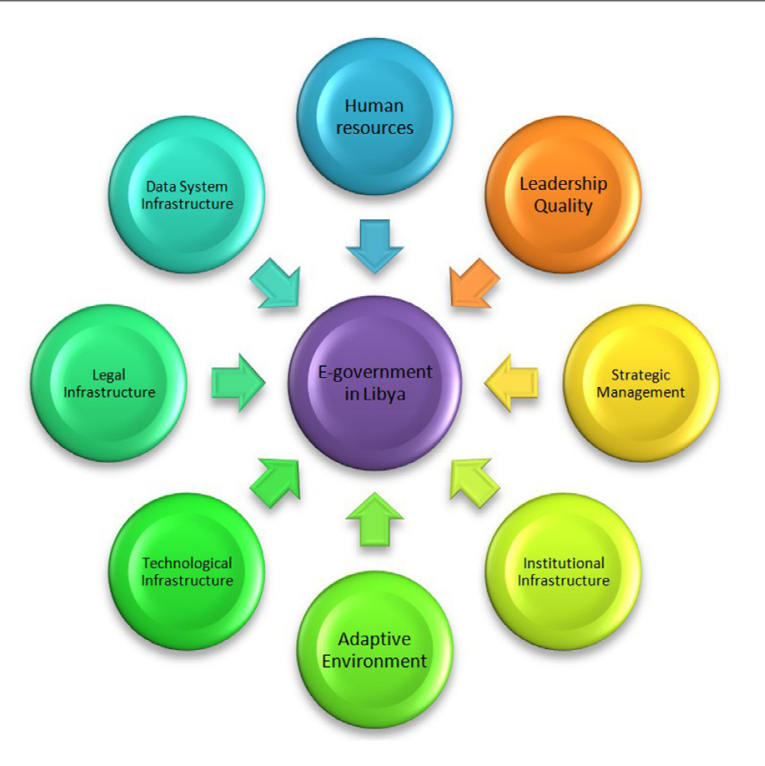

Picture 1. Infrastructure needed for quality e-government
"World Bank" has given the definition of E-government. It refers to implementation of Information and Communication Technologies (ICT) in work of government with the aim to find the easiest way of communication with public and private sector [10]. E-government is represented by web site, which contains relevant information or issues that are important for citizens or businesses [2].

\section{IMPLEMENTATION OF E- GOVERNMENT IN LIBYA}

Official websites posted by North African governments give excellent opportunities to get access to government's information, such as: Morocco, Algeria, Tunisia, Libya, Egypt, and Sudan [1]. In order to establish strong institutions, and a stable legal framework, the government needs to provide stable economic situation. Desired state for government to make sure that its initiative is efficiently implemented and that the desired goal of process is achieved, is to govern Libya in two mandates.

\begin{tabular}{ll}
\hline Population & $6,411,776$ (July 2015 est.) \\
\hline Literacy Rate & $91 \%$ (Ranks 13 in the World) [UN] \\
\hline $\begin{array}{l}\text { International Pov- } \\
\text { erty Line Popula- } \\
\text { tion }\end{array}$ & $7.2 \%$ [UNDP] \\
\hline $\begin{array}{l}\text { No. of Schools } \\
\text { (Public, Private, }\end{array}$ & 6586 \\
$\begin{array}{l}\text { Kindergarten, } \\
\text { International, } \\
\text { Technical) }\end{array}$ & \\
$\begin{array}{l}\text { Telephones - mo- } \\
\text { bile cellular }\end{array}$ & 10.1 million \\
\hline \begin{tabular}{l} 
Internet users \\
\hline
\end{tabular} & 1.4 million (21.8\% (2014 est.) rank 114 \\
\hline
\end{tabular}

Table I. ICT and educattional infrastructure of Libya [5]

After the time that has led to Libyan Revolution, the Ministry of communication and informatics proposed many initiatives to use technology to support government operations and to enhance the services provided to all citizens and businesses in Libya [13]. Despite numerous problems that Libya inherited from the former regime, and new problems that accompany political, social and economic reforms, it created some important websites and E-projects, which have increased the utilization rate and the presentation of the web on Libyan territory. Because of political insecurity and many other problems that transitional country has to overcome Libya has not achieved desired goals. The country hes high literacy 
rate among the citizens and that is the great potential for these kinds of modernization processes [9]. Great problem is the security and privacy issue.

Numerous challenges are also encountered in political, economic, social and technological aspects.

By observing the social aspect of Libya, we can notice lack of IT experts, despite high literacy rate that places Libya in the 18th place on the world list. These demanding jobs are usually performed thru experts from other countries. Owing to the lack of IT skilled workforce, there is no competitive environment and therefore the need for continuous knowledge improvement is very small.

Political weakness for establishing good E-government practice is in poor legislation framework for IT sector that is departing potential investments in development of this sector and re-building infrastructure. Another problem is in great number of employees in public sector, which has no motivation to accepting Egovernance, because this advanced system brings considerable savings, savings and greatly reduces the need for many employees. Validity of digital signature, cyber protection and acceptance of information from Internet source by government officials are also the problems that need to be solved [3].

Despite the high investment return potential, there is still lack of investors and small budget funding. Technological problems include bad infrastructure and lack of IT standards and software licenses.

The case of E-government in Libya is still in process. The purpose of the project is to reduce time loss in transaction over in all cities in the country, mainly the capital (Tripoli) [3].

United Nation Development Program (UNDP) is a partner with Libyan Government in its E-government strategy of modernizing the systems of the Libyan Government and offering citizen access to government services through technology. UNDP is currently supporting with the E-government team in setting up a Project Management office, and assisting with the assessments and coordination of three line Ministries: Industry, Health and Education [12].

UNDP will also transfer knowledge initiatives where lessons, which will be learned and a range of international experiences will be introduced to Libyan stakeholders. This is the beginning of a partnership with the Libyan government in an effort to modernize and deliver citizen services in a more effective way [12].

Poor access to ICT's and lack of educational possibilities caused by turbulent events in Libya might slow down the development of public services and e-government.

\section{PLANS FOR IMPROVING E-GOVERNANCE IN LIBYA}

Libya has instruments for developing a detailed strategic plan to make the process of developing stable and efficient E-government system as simple and easy as it is possible. This is especially important for parts of the country that are far from big cities and places that built strong and well organized local governing.

The purpose of E-government is that private and public sector can get easy access to government services.

In addition, e-government usage is important for main systems of the country (health care, education, civil and private sector) [4].

In order to improve the country's state particularly after the "Civil War", Libyan E-government should improve all web sites of the government as well to educate government employees [6].

Currently, Libyan e-government web sites are trying to present the basic information for its citizens and give contribution to reduce gender or social obstacles, as well as geographic distance between administrative centers.

According to the problem motioned above ("Civil War") and economic crisis, the e-government of Libya is still struggling with infrastructure problems. Therefore, the costs of transactions are still very high.

Furthermore, literacy about Internet technologies (IT) is still on very low level, which is a big concern for the government as well for the citizens. There is a future plan for integration of ICT in educational system and Libya is looking for international support [6].

In order to develop a comprehensive strategy and to determine the roadmap for the implementation of key elements of E-government, National Transitional Council (NTC) has contracted with Price Waterhouse Coopers (PwC) [8].

Required work is best implemented in several stages:

- First stage is evaluation stage that represents assessment of the current situation.

- Second stage is creating a new framework strategy of local E-government.

- Third stage is the development of: infrastructure of the country, inter-governmental communication, E-services applications for E-government. 
- Fourth stage is the development of a plan for the implementation of E-government project;

- Fifth stage represents E-government management project.

- Sixth stage represents creation of educational system for E-government.

- Seventh stage is representing a creation of basic frameworks for E-learning, E-healthcare and Ecommerce systems.

- Eighth stage consists of different issues: education system, project management, quality assurance [8].

\section{COOPERATION WITH COUNTRIES WITH GOOD E-GOVERNMENT PRACTICE}

Using advanced technologies within E-government services is everyday practice mostly used by developed economics in the world. Accepting this practice from the country that has a stable economic situation and experience like the UK could be extremely valuable for Libya and its people.

Since 2012 Libyan governments have mad a few agreements with Great Britain for developing communications infrastructure in Libya. [11]

Two governments agreed that Libya should accept the model of E-government of Great Britain, which contains three main points:

1. Information and Communication Technology (ICT)

2. Regulatory framework

3. ICT applications, particularly E-government, Ecommerce and E-learning [11].

The goals of this cooperation are identifying opportunities for investments in Libya, development of government services, advancing and establishing infrastructure, bringing up technological innovation systems, and improving the coordination of personnel.

These activities between two governments include:

1. Exchange of technical experts, in order to provide technical and strategic guidance, training, and education.

2. Creating better infrastructure mainly, basic access to the internet, designing policies for management of the telecommunications market;

3. Additional tasks in order to finalize the projects [11].

\section{CONCLUSION}

Libya is a very unstable situation. The country has impressive literacy rate among the population, but the major issue is that there is less personnel with Information Technology (I.T.), skills. Social factors exert considerable impact on implementation of new technologies. A large number of Libyan citizens don't accept this kind of communication system, because of many reasons such as low educational system possibility of using new technology, high cost of implementing new technology. Infrastructure is still developing and there is a vast number of projects that should be done such as electricity, and missing of Internet stations, and communication between south and north, because of vast territory between the cities. Libya is in its early stage of E-government development, and there is much more to be done. Planning, utilization of resources and positive efforts of governance could put Libya in the future with developed countries. Communication and collaboration with developed countries like UK could bring major results to this project.

\section{REFERENCES}

[1] Adams Dr Carl., (2015), Proceedings of the 15th European Conference on e-Government 2015: ECEG 2015, Academic Conferences Limited, p. 398

[2] Alshboul, R., (2012), Security and Vulnerability in the E-Government Society, Contemporary Engineering Sciences

[3] Forti, Yousef; Bechkoum, Kamal; Turner, Scott; Ajit, Suraj, (2014), The Adoption of e-Government in Arab Countries: The Case of Libya, Proceedings of the European Conference on e-Government, Romania

[4] International Labor Office Geneva, (2008), Skills for improved productivity, employment growth and development, Retrieved February, 25, 2016, from http://www.ilo.org/wcmsp5/groups/public/@ed_ norm/@relconf/documents/meetingdocument/ wcms_092054.pdf

[5] Internet Usage Statistics for Africa (Africa Internet Usage and 2015 Population Stats), retrieved February 21,2016 , from http://www.internetworldstats. com/stats1.htm

[6] Jones Chris, Kennedy S., Kerr S., (2012), Furthering Democracy In Libya with Information technology: Opportunities For the International Donor Community, The Centre for International Governance Innovation (CIGI) 
[7] Libyan Electronic portal retrieved March 11, 2016, from http://lip.gov.ly/portal/page?_pageid=53,1\&_ dad=portal\&_schema=PORTAL

[8] PricewaterhouseCoopers, (2013), Creating Value for Government Retrieved February 27, 2016, from https://www.pwc.com

[9] Saadi, M., \& Almahjoub, A., (2012), E-Governance in Libya -Where we are and Where to Go, The International Libyan Conference on Electronic Government, Tripoli -Libya

[10] The World Bank. Definition of E-government retrieved March 10, 2016 from http://go.worldbank. org/M1JHE0Z280
[11] UK and Libya agreement on open government Retrieved March 11, 2016, from https://www.gov.uk

[12] UNDP Libya, (2013), Newsletter September 2013, Retrieved February 21, 2016, from http://www. ly.undp.org/content/dam/libya/docs/Newsletter/ newsletter3_10_2013\%20Eng.pdf

[13] UNPAN, (2013), E-Government: Libyan Plan towards Better Services, Retrieved January 31, from http:// www.tripolipost.com/articledetail.asp?c=1\&i=10446 